\title{
Response to: "More on the Limitations of the aPTT for Monitoring Argatroban Therapy"
}

\author{
Elizabeth M. Van Cott, MD ${ }^{1}$ A. Joshua Roberts, PharmD² William E. Dager, PharmD²
}

${ }^{1}$ Department of Pathology, Massachusetts General Hospital, Boston, Massachusetts

2 Department of Pharmacy, University of California Davis Medical Center, Sacramento, California

Semin Thromb Hemost 2017;43:644.

We thank Guy et al for their interest and kind words regarding our article on laboratory monitoring of parenteral direct thrombin inhibitors ${ }^{1,2}$ and for sharing their valuable new data. ${ }^{2}$ Their finding that different activated partial thromboplastin time (aPTT) reagents differ in their responsiveness to argatroban is reminiscent of the problem seen with differing aPTT reagent responsiveness to heparin. We agree with their commentary that increased use of drug-calibrated specific assays would be beneficial for patients. Currently, this is limited by the lack of an approved assay in many countries such as the United States. Assay(s) are approved for use in certain other regions such as Canada (Health Canada licensed) and Europe (CE marked). In locations without access to drug-calibrated assays, clinicians suspicious of high aPTT values flat lining may consider other laboratory measures such as a rising international normalized ratio despite no change in the aPTT or rising thrombin time as an additional means to identify the potential for high argatroban or bivalirudin concentrations.

We also agree that more data are needed to help establish the therapeutic range for argatroban concentration, as published ranges have varied. To add to the studies cited by Guy et $\mathrm{al}^{2}$ and others, ${ }^{3}$ Ahmad et $\mathrm{al}^{4}$ reported an argatroban range of 1.2 to $2.3 \mathrm{ug} / \mathrm{mL}$ (by high-performance liquid chromatography) in patients with heparin-induced thrombocytopenia (HIT) receiving argatroban in the ARG-911 trial, which is the highest range we have seen.
Address for correspondence Elizabeth M. Van Cott, MD, Department of Pathology GRJ235 Massachusetts General Hospital, 55 Fruit Street, Boston MA 02114 (e-mail: evancott@mgh.harvard.edu).

This high range, along with lower ranges published by other studies, influenced the selection of the tentative range of 0.6 to $1.8 \mathrm{ug} / \mathrm{mL}$. It is possible that lower target ranges may be considered in patients with bleeding risks and isolated HIT compared with those with recent, new thrombosis. We look forward to additional studies that help finalize the argatroban therapeutic range. It will be important as new methods are proposed and target ranges established to assure that values reported among different clinical laboratories and methods are consistent and specific to the anticoagulant being used, easy to perform in a timely manner, and applicable to the population being managed.

\section{References}

1 Van Cott EM, Roberts AJ, Dager WE. Laboratory monitoring of parental direct thrombin inhibitors. Semin Thromb Hemost 2017; 43(03):270-276

2 Guy S, Van Veen J, Kitchen S. More on the limitations of the APTT for monitoring argatroban therapy. Semin Thromb Hemost 2017; 43(06):642-643

3 Love JE, Ferrell C, Chandler WL. Monitoring direct thrombin inhibitors with a plasma diluted thrombin time. Thromb Haemost 2007;98(01):234-242

4 Ahmad S, Iqbal O, Ahsan A, et al. Clinical laboratory monitoring of a synthetic antithrombin agent, argatroban, using high performance liquid chromatography and functional methods. Int Angiol 1999;18(03):198-205 published online June 13, 2017
Issue Theme Editorial Compilation IV; Guest Editors: Emmanuel J. Favaloro, PhD, FFSc (RCPA), and Giuseppe Lippi, MD.
Copyright (c) 2017 by Thieme Medical Publishers, Inc., 333 Seventh Avenue, New York, NY 10001, USA. Tel: +1(212) 584-4662. ISSN 0094-6176. 